\title{
МОНГОЛ ОРНЫ ХАЙЛУУР ЖОНШ ДЭЛХИЙН ЗАХ ЗЭЭЛД ГАРАХДАА ЯМАР ТЕХНОЛОГИОР БОЛОВСРОГДОН ГАРДАГ ТАЛААР
}

\author{
Б.Нямдаваа, С.Баяраа \\ Эрдэ боловсруулалтын технологийн хүрээлэн, ШУА \\ Цахим муудан: narsar54@yahoo.com, s.bayar9@gmail.com
}

\begin{abstract}
Хураангуй
Судалгааны энэхүУ өгүүлэлд хайлуур жоншны хэрэглээ, зах зээл, Монгол орны хайлуур жоншны баяжуулалтын арга хэв маяг, төлөөлөл болгож Хэнтий аймгийн Бор-Өндөр суманд орших “ХУдрийн биет 16-3” ордын дээжинд баяжигдах чанарын судалгаа явуулан ур дүнг оруулав.
\end{abstract}

$\boldsymbol{T}_{\boldsymbol{Y} л х \boldsymbol{Y ү}} \boldsymbol{Y}^{2}$. Хайлуур жоншны орд, баяжуулалт, боловсруулалт, металл авалт-є, агуулга- $\beta$, гари- $\gamma$

\section{ОРШИЛ}

Манай улс хайлуур жоншны арвин их нөөцтэй хэдий ч эцсийн бүтээгдэхүүн болгон орчин үеийн технологиор боловсруулж нэмүҮ өртөг шингээн олон улсын зах зээлд гаргаж чадахгүй байна. Өөрөөр хэлбэл гар аргаар ялган түүхийгээр нь экспортлож байгаа нь тухайн хайлуур жоншийг үнэлүүлэх чадамж нь муу байгаа юм. Монгол орны зүүн урд хэсгээс эхлэн Хэнтий аймгийг дайран хайлуур жоншны томоохон бассейн (илэрц) байдаг бөгөөд энэ бүсэд жоншны баяжмалыг үйлдвэрлэлийн түвшинд боловсруулан гаргаж байгаа үйлдвэр Бор-Өндрийн уулын баяжуулах үйлдвэрээс өөр үйлдвэр одоог хүртэл ажиллаагүй байгаа нь экспортын жонш хямд үнээр гарж байгааг илэрхийлж байна. Ирээдүйд жоншны ордуудыг даган баяжуулах үйлдвэрүүд баригдан ажиллахаар төсөл боловсрогдон эхнээсээ барилын ажилаа эхлүүлж байгаа нь сайшаалтай юм. Бор-Өндөр, Дорноговийн бүсийн жонш олборлогчид агуулга хөөн сорьцлон олборлож байгаа нь ирээдүйд жоншны нөөцийг бууруулж болзошгүй байна. Мөн үлдсэн бага агуулгатай жоншны хүдрийг дараа нь олборлон баяжуулахад хүндрэлтэй байх болно. Иймд энэ бүс газар жонш баяжуулах бага оврын үйлдвэрүүд баригдаж жонш олборлогчид бага агуулгатай хайлуур жоншийг баяжуулах нь эдийн засаг хувьд өгөөжтэй алхам юм. $\mathrm{CaF}_{2}-$ ийн агуулгаар нь хайлуур жоншийг зэрэглэн (1-р хүснэгт) үзэж зах зээлд борлуулдаг байна.

\section{Хайлуур жоншны үйлдвэрлэл, хэрэглээ.}

1868 оны үеэс энэхүү эрдсийг дэлхий нийтээрээ "Fluorite" хэмээн нэрлэх болсон бөгөөд энэ нь Латин хэлний "Fluere" буюу "урсах" гэсэн үгнээс гаралтай. Тухайн үеэс жоншийг гоёл чимэглэл, гар урлал, засал чимэглэлд хэрэглэхээс гадна ган хайлуулахдаа шингэрүүлэгч болгон хэрэглэж байжээ. Хайлуур жоншны найрлагын 51.1 хувийг кальци (Са), 48.9 хувийг фтор (F) бүрдүүлдэг, метал бус эрдэс юм. 19-р зуунд ган хайлуулахад хайлуур жоншийг өргөн хэрэглэдэг байсан бол өнөө үед гангийн буюу төмрийн хайлш бэлтгэх, хөнгөн цагааны үйлдвэрлэл, гагнуурын электродын бүрхүүл, гангийн цутгуур, цементийн үйлдвэр, тусгай зориулалтын оптик шил үйлдвэрлэх, фторт устөрөгчийн 
хүчил болон бусад фторт нэгдлүүдийг гарган авахад ашиглаж байна. Өнөөгийн байдлаар дэлхийн хэмжээнд жилд 5.7-
6.0 сая орчим тонн хайлуур жоншны бүтээгдэхүүн үйлдвэрлэж, хэрэглэж байна. (Зураг 1, 2, 3)

Хүснэгт 1

Металлургийн жонщны ангилал

\begin{tabular}{|c|c|c|c|c|l|}
\hline \multirow{2}{*}{ Зэрэг } & \multirow{2}{*}{$\begin{array}{c}\text { Сағ2 } \\
\end{array}$} & \multicolumn{2}{|c|}{ Хорт хольц $(\leq), \%$} & \multirow{2}{*}{ Зориулалт } \\
\cline { 3 - 5 } & & $\mathrm{SiO}_{2}$ & $\mathrm{~S}$ & $\mathrm{P}$ & \\
\hline 1 & 95 & 4.7 & 0.1 & 0.06 & Онцгой төрлийн ган, хайлш боловсруулахад \\
2 & 90 & 9.0 & 0.1 & 0.06 & Онцгой төрлийн ган, хайлш боловсруулахад \\
3 & 85 & 14.0 & 0.1 & 0.06 & Дээд зэргийн ган боловсруулахад \\
4 & 80 & 19.0 & 0.15 & 0.06 & Ердийн ган боловсруулахад \\
5 & 75 & 23.0 & 0.15 & 0.06 & Ердийн ган, төмөр боловсруулах, төмөр хайлах \\
6 & 70 & 28.0 & 0.15 & 0.06 & Төмөр хайлах, боловсруулахад \\
7 & 65 & 32.0 & 0.15 & 0.06 & Төмөр хайлах, боловсруулахад \\
\hline
\end{tabular}

Дэлхийн хайлуур жоншны үйлдвэрлэлийн хувь хэмжээ (улсаар)

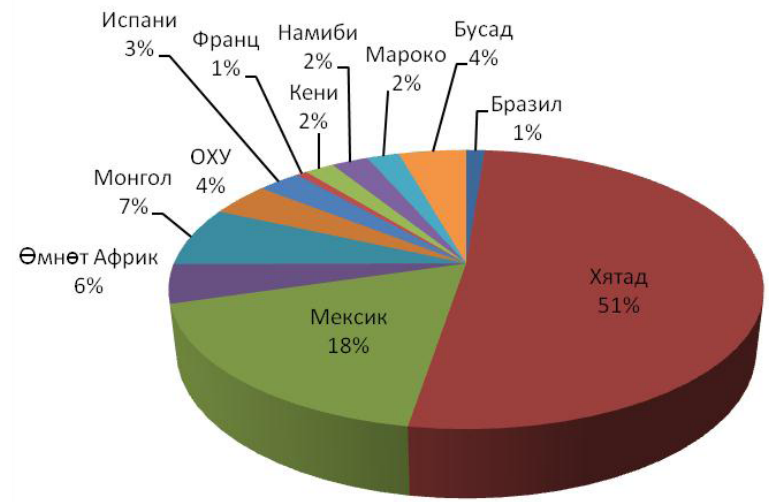

1-р зураг.

Дэлхийн хайлуур жоншны хэрэглээ (улсаар)

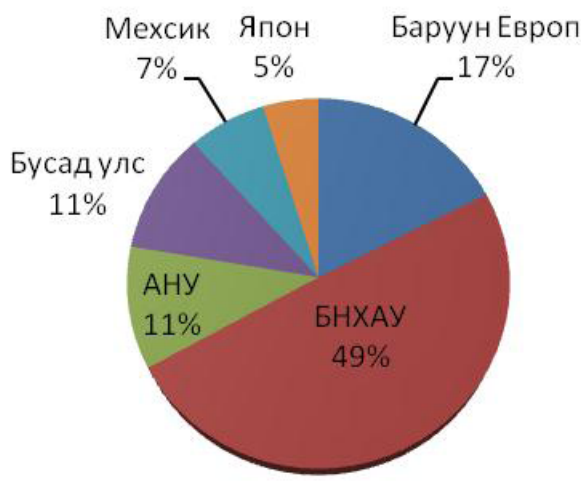

2-p зураг 


\section{Хайлуур жоншны хэрэглээ \\ (салбараар)}

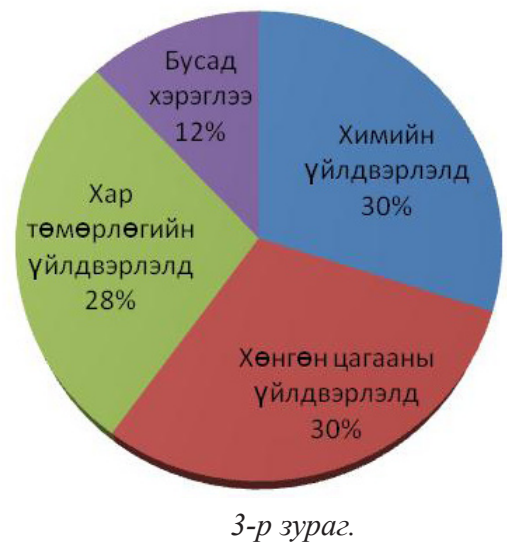

\section{Монгол улсын хайлуур жоншны бүтээгдэхүүн үйлдвэрлэл}

Монгол улс жилд 300-460 мянган тонн хайлуур жоншны бүтээгдэхүүн үйлдвэрлэж байна. Хайлуур жоншны бүтээгдэХүҮн үйлдвэрлэлтийн сүүлийн 10 жилийн хэмжээг Хүснэгт 1-д үзүүлэв.

Хуснэгт 2

\begin{tabular}{|c|l|c|c|c|c|c|c|c|}
\hline & \multicolumn{1}{|c|}{ Бүтээгдэхүун } & 2005 & 2006 & 2007 & 2008 & 2009 & 2010 & $2011^{*}$ \\
\hline 1 & $\begin{array}{l}\text { Бүхэллэг жонш, } \\
\text { мян.тн }\end{array}$ & 233.4 & 239.4 & 245 & 219.1 & 244.2 & 278.2 & 300.0 \\
\hline 2 & $\begin{array}{l}\text { Флотацын баяжмал, } \\
\text { мян.тн. }\end{array}$ & 93.7 & 108.3 & 131.8 & 142.9 & 115.3 & 140.7 & 116.4 \\
\hline
\end{tabular}

Манай орны хувьд хайлуур жоншны БНСУ, Энэтхэг, Япон зэрэг улс орнуудад бүтээгдэхүүнээ ОХУ, БНХАУ, АНУ, Украйн, экспортлож байна.

Хуснэгт 3

Дэлхийн хайлуур жоншны нөөи

\begin{tabular}{|l|r|r|r|r|}
\hline \multirow{2}{*}{\multicolumn{1}{|c|}{ Улс орнууд }} & \multicolumn{2}{|c|}{ Бодит нөөц } & \multicolumn{2}{c|}{ Боломжит нөөц } \\
\cline { 2 - 5 } Бразил & Хэмжээ, мян.тн & \multicolumn{1}{c|}{ Хувь, \% } & \multicolumn{1}{c|}{ Хэмжэ, мян.тн } & \multicolumn{1}{|c|}{ Хувь, \% } \\
\hline Хятад & 1000.0 & 0.4 & 3000.0 & 0.6 \\
\hline Мексик & 21000.0 & 8.8 & 110.000 & 22.9 \\
\hline Өмнөд Африк & 32.000 & 13.3 & 40.000 & 8.3 \\
\hline Монгол & 41.000 & 17.1 & 80.000 & 16.7 \\
\hline ОХУ & 12.000 & 5.0 & 16.000 & 3.3 \\
\hline Испани & - & - & 18.000 & 3.8 \\
\hline Франц & 6.000 & 2.5 & 8.000 & 1.7 \\
\hline Кени & 10.000 & 4.2 & 14.000 & 2.9 \\
\hline Намиби & 2.000 & 0.8 & 3.000 & 0.6 \\
\hline Мороко & 3.000 & 1.3 & 5.000 & 1.0 \\
\hline Бусад & - & - & & - \\
\hline \multicolumn{1}{|c|}{ Дүн } & 112.000 & 46.7 & 183.000 & 38.1 \\
\hline
\end{tabular}




\section{Хэнтий аймгийн Бор-Өндөр сумын \\ “Хүдрийн биет 16-3” ордын хайлуур жоншны хүдрийг баяжуулсан судалгааны үр дүн}

Тус ордын хүдрийн дээжний бодисын найрлагын судалгаа, спектрийн, эрдсийн, химийн, шигшүүрийн шинжилгээнүүдийг хийлээ. Хайлуур жоншны баяжуулалтын туршилтыг 2 хувилбараар явуулах схем зохиож, 1-р хувилбар нь хүдрээс хайлуур жоншны баяжмалыг \75--92\%-ийн $\backslash$ гар аргаар ялгаж авах боломжийн судалгаа, туршилт;2-рхувилбарньхүдрийгфлотацийн аргаар баяжуулж супер баяжмал гарган авах ажлуудыг гүйцэтгэв. Флотацийн туршилтыг явуулахын тулд нунтаглалтын зохистой хугацааг тодорхойлох туршилтуудыг явуулсан. Туршилтын үр дүнгээр дээжийг 40 минут нунтаглаж нийт 10 минут флотацилах хугацаа хамгийн зохистой гэж Үзэн сонгов. Урвалжийн зохистой горим тодорхойлох туршилт судалгааг цуглуулагч урвалж болох олеат натри, дарагч- шингэн шил, хөөсрүүлэгч -Т-66 зэргийг ашиглан явуулж хамгийн сонгомол зарцуулалтыг технологийн үзүүлэлтүүд дээр тулгуурлан тогтоов.Флотацийн кинетик явуулж үндсэн болон хяналтын баяжуулалтын зохистой хугацааг тодорхойлсон. Үндсэн флотацийг 6 минут, хаягдал дахь $\mathrm{CaF}_{2}$-ийн алдагдлыг багасгахын тулд хяналтын флотациыг 4 минут байхаар тогтоов. Бүтээгдэхүүн дэхь $\mathrm{CaF}_{2}$-ийн агуулгыг нэмэгдүүлэх боломжийн судалгааг явуулав. Үүний тулд баяжмалыг 2 удаа цэвэрлэхэд \олеат натри, дарагч зэргийг бууруулсан тунгаар өгч $\mathrm{CaF}_{2}$-ийн агуулгыг өсгөн 93,5\% -ийн чанартай, 82,52\%-ийн авалттай хайлуур жоншны баяжмал гарган авч болохыг тогтоов.

\section{ХАЙЛУУР ЖОНШНЫ БУХЭЛ БАЯЖМАЛ ГАРГАН АВАХ ТУРШИЛТ}

Анхдагч хүдрийн хамгийн том мөхлөгийн хэмжээ-200+20мм. Гарялгалтад-100+20ммийн хэмжээтэй бүхэл хэсэг хамрагдав. Гар аргаар $\mathrm{CaF}_{2}-\mathrm{H}$ өндөр, дунд, бага агуулгатай бүхэллэг баяжмалын бүтээгдэхүүн болох хэсгийг нүдэн баримжаагаар дөрвөн төрөлд ялгаж авсаны дараа бүхэллэг баяжмалын агуулгыг химийн шинжилгээгээр тогтоосон болно. Үр дүнг хүснэгтэнд үзүҮлэв.

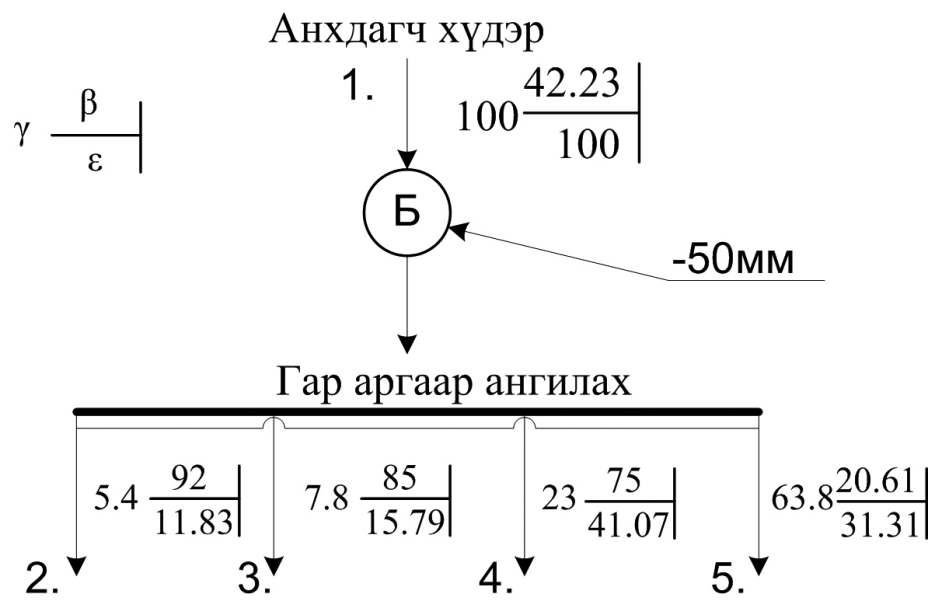

4-р зураг Хайлуур жоншны баяжмальг гар аргаар ялгах схем 
Гар аргаар ялган авсан хайлуур жоншны баяжмальн технологийн ҮзҮҮлэлтүҮд

\begin{tabular}{|c|c|c|c|c|c|c|}
\hline Бүтээгдэхүүн & Гарц, кг & Гарц \% & $\begin{array}{l}\text { Агуулга } \\
\mathrm{CaF}_{2}, \%\end{array}$ & $\begin{array}{c}\text { Жонш } \\
\text { авалт, \% }\end{array}$ & $\begin{array}{c}\mathrm{CaCO}_{3}, \\
\%\end{array}$ & $\begin{array}{l}\mathrm{SiO} 3 \\
\%\end{array}$ \\
\hline $\begin{array}{l}\text { 92\%-ийн } \\
\text { агуулгатай жонш }\end{array}$ & 3.96 & 5.40 & 92 & 11.83 & 0.96 & 6.5 \\
\hline $\begin{array}{l}\text { 85\%-ийн } \\
\text { агуулгатай жонш }\end{array}$ & 5.72 & 7.80 & 85 & 15.79 & 0.81 & 12.3 \\
\hline $\begin{array}{l}\text { 75\%-ийн } \\
\text { агуулгатай жонш }\end{array}$ & 16.86 & 23.00 & 75 & 41.07 & 0.79 & 21 \\
\hline $\begin{array}{l}\text { Хаягдал 23\%-ийн } \\
\text { агуулгатай жонш }\end{array}$ & 46.77 & 63.80 & 20.61 & 31.31 & 0.82 & 58.24 \\
\hline Анхдагч хүдэр & 73.3 & 100.00 & 42 & 100 & 0.82 & 43.3 \\
\hline
\end{tabular}

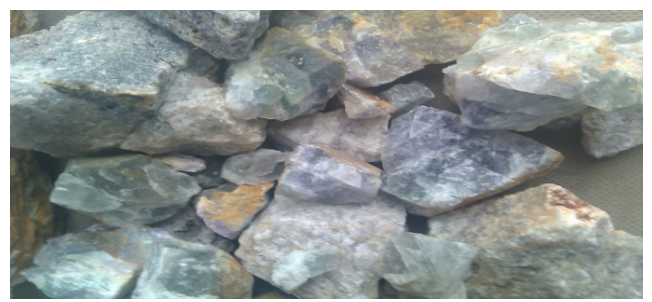

5-р зураг. 92\%-ийн СаF бүхэллэг хайлуур жонш

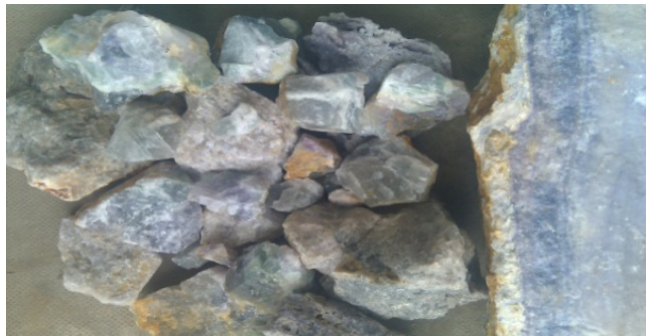

6-р зураг. 85\%-ийн СaF2-ийн агуулгатай бүхэллэг хайлуур жонш

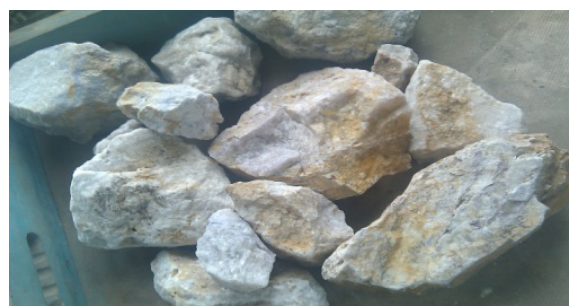

7-р зураг. 75\%-ийн СаF2-ийн агуулгатай хайлуур жонш

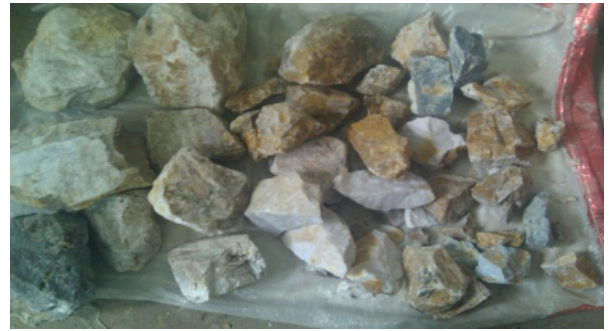

8-р зураг. 20.61\%-ийн СаF2-ийн агуулгатай флотаиийн $х ү д э р$

\section{ХАЙЛУУР ЖОНШНЫ ФЛОТАЦИЙН ТУРШИЛТ ШИНЖИЛГЭЭ}

1. Флотацийн туршилтыг явуулахын тулд гар аргаар ялгалт явуулсан хүдрийн хамгийн ядуу агуулгатай $\left(\mathrm{CaF}_{2}-\mathrm{H}\right.$ агуулга-20.61\%) жижиг ширхэгтэй үлдэгдэл хэсгийг баян хүдэртэй нийлүүлэн $\mathrm{CaF}_{2}-$ ийн агуулгыг $38-42 \%$-ийн агуулгатай болтол дундажлан бэлтгэх ажиллагааг явуулсан. Үүний үр дүнд флотацид орох хүдрийн дундаж агуулга $41,10 \%$ болсон. Агуулгыг химийн шинжилгээгээр тогтоосон болно.

2. Флотацийн схемийн горимыг боловсруулан туршилт шинжилгээг явуулсан. Цуглуулагч - олеат 
натри, дарагч- шингэн шил, орчин тохируулагч -содын, хөөсрүүлэгчТ-66 урвалжуудыг сонгон авсан. Урвалжуудын сонголтыг хийхдээ тэдгээрийн түгээмэл хэрэглээ, үнэ ханш болон хамгийн гол үзүүлэлт болох үйлчлэлийн идэвхи зэргийг харгалзан авсан болно.

Нунтаглах хугацааны өөрчлөлт бүрээр явуулсан туршилтын дүн

Лабораторийн туршилтын үр дүнгээс баяжмалын гарц болон металл авалт нунтаглах хугацаа нэмэгдэх тусам буурч байна. Үүнд дээжийг 40 минут нунтаглаж, 10 минут флотацлахад баяжмалын гарц 78,99\%; авалт 96,76\% хүрэв. Харин нунтаглах хугацааг цаашид нэмэхэд баяжмалын чанар нэлээд буурах хандлагатай байгаа тул нунтагласан хүдэр дэх зохистой ангийн агуулга (-75мкм) $77,80 \%$ буюу нунтаглах хугацаа 40 минут байхаар тогтов. $\begin{array}{cccc}\text { Орчин тохируулагч урвалж } & \text { содын } \\ \left(\mathrm{Na}_{2} \mathrm{CO}_{3}\right) \text { зарцуулалтыг тогтоох } & \\ \text { Туршилтын } \text { үр дүнгээр } & \text { содын }\end{array}$ зарцуулалтын 1000 г/т-д бохир баяжмалын гарц $42,69 \%$, авалт $87,91 \%$-д хүрэв. $\mathrm{Na}_{2}$ $\mathrm{CO}_{3}$-ийн зарцуулалт нь 1500г\т дэээш $\mathrm{CaF}_{2}-\mathrm{H}$ авалт буурах хандлага харагдаж байна.

Дарагч урвалжийн зарцуулалтыг тодорхойлох туршилт

Туршилтын үр дүнгээр $\mathrm{Na}_{2} \mathrm{SiO}_{3}$ -500г/т зарцуулалтыг сонгов. Түүнээс дээш зарцуулалтад хайлуур жоншны авалт буурах төлөвтэй бана.

Цуглуулагч урвалжийн зарцуулалтыг тодорхойлох туршилт

Туршилтын үр дүнгээс харахад олеат натрийн зарцуулалт 300гіт -д жоншны агуулга $84,64 \%$ хүртэл өсч, авалт $87,91 \%$-д хүрэв. Гарц $42,69 \%$ байна. Цуглуулагчийн зарцуулалтыг цаашид нэмэгдүүлэх тусам авалт өссөөр байна.

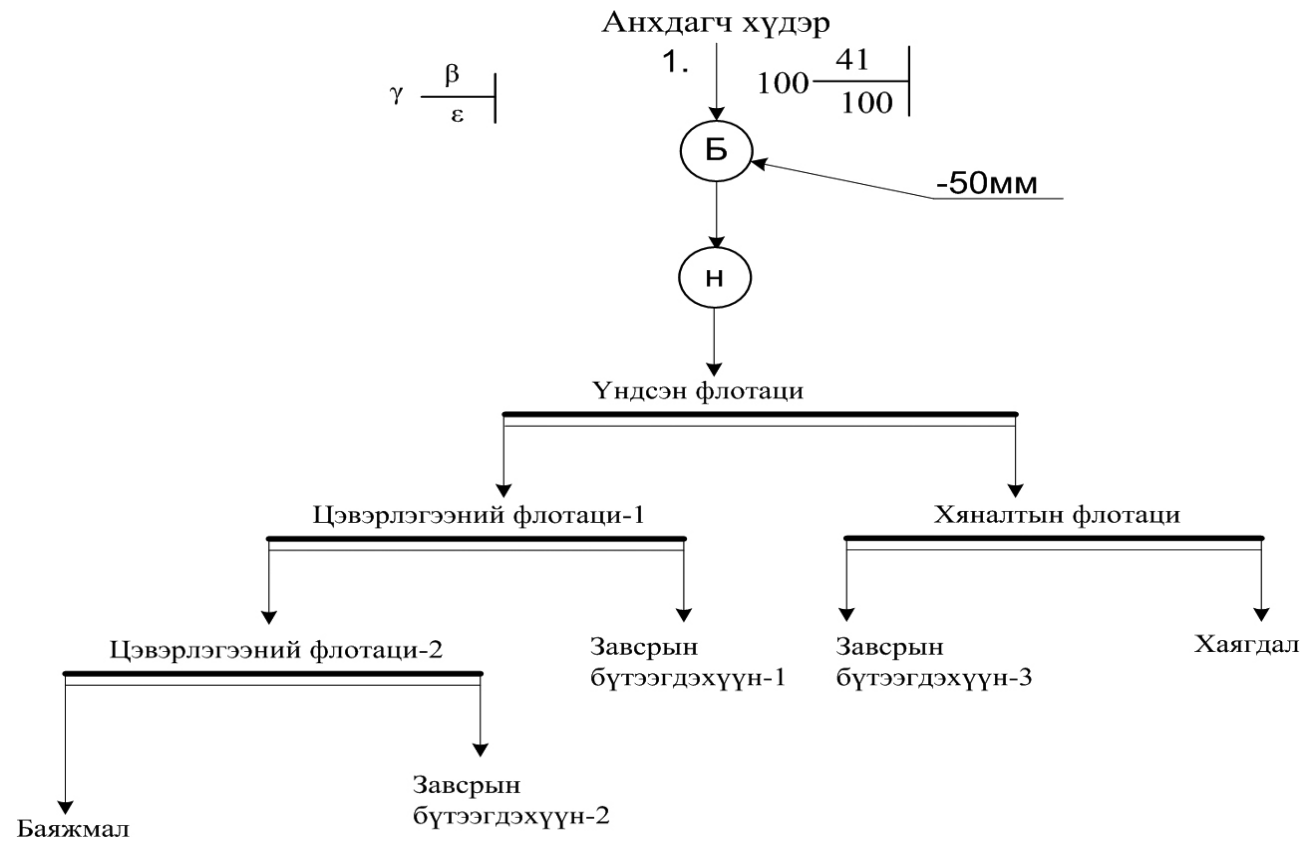

9-р зураг. Флотащийн аргаар баяжуулсан технологийн задгй схем 
ХҮснэгт 5

флотацийн баяжуулалтын металлын баланс

\begin{tabular}{|c|c|c|c|c|}
\hline \multirow[t]{2}{*}{ Бүтээгдэхүүний нэр } & Гарц & $\begin{array}{c}\text { Агуулга, } \\
\%\end{array}$ & $\begin{array}{c}\text { Авалт, } \\
\%\end{array}$ & \multirow[t]{2}{*}{ Туршилтын нөхцөл } \\
\hline & $\%$ & $\mathrm{CaF}_{2}$ & $\mathrm{CaF}_{2}$ & \\
\hline Баяжмал & 36,15 & 93,81 & 82,52 & \multirow{6}{*}{ 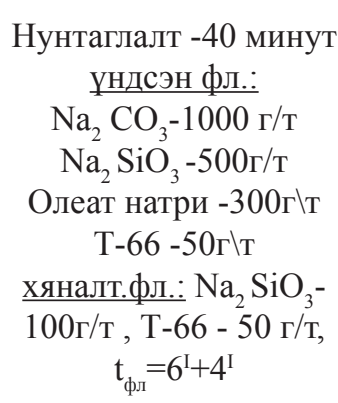 } \\
\hline Завсрын бүтээгдэхүүн 1 & 3,23 & 31,44 & 2,48 & \\
\hline Завсрын бүтээгдэхүүн 2 & 1,15 & 51,44 & 1,44 & \\
\hline Завсрын бүтээгдэхүүн 3 & 2,15 & 27,98 & 1,47 & \\
\hline Хаягдал & 57,31 & 8,67 & 12,09 & \\
\hline Анхдагч хүдэр & 100,0 & 41,10 & 100,0 & \\
\hline
\end{tabular}

\section{ДҮГНЭЛТ}

1. Хүдрийн баяжигдах чанарын судалгааны дүнд дараах үр дүнг гарган авсан. Үүнд: хайлуур жоншийг гар аргаар 4 төрлийн бүхэллэг баяжмал нүдэн баримжаагаар ялган авсан ба баяжмал бүрийн $\mathrm{CaF}_{2}$-ын агуулга $92,0 \%, 85,0 \%, 75,0 \%, 20,61 \%$ байв. Тэдгээрийн гарц харгазан - 3,96\%, $5, .76 \%, \quad 16,86 \%, \quad 46,77 \%$ ба авалт харгалзан $11,83 \%, \quad 15,79 \%, 41,07 \%$, $31,31 \%$ байна.

2. Гар аргаар ялгасан анхдагч хүдрийн үлдэгдэл хэсгийг $120,61 \%$-ийн $\mathrm{CaF}_{2}$-ын агуулгатай\ баян хүдэртэй нийлүүлэн дундажлан флотацид бэлтгэн флотацийн аргаар баяжуулах туршилт шинжилгээг явуулан баяжмалын $\mathrm{Ca}_{\mathrm{F} 2}$ -ын агуулга 93,15\%, гарц-36,15\%, авалт 82,52\%-тай бүтээгдэхүүн гарган авсан. Флотацийг 2 цэвэрлэгээтэй явуулсан бөгөөд баяжмал нь хайлуур жоншны ФФ-92 маркийн техникийн шаардлага хангасан бүтээгдэхүүн болно. Баяжмалын чанарыг өсгөж түүнд агуулагдах кварц, карбонатын агуулгыг бууруулахад \брикетийн шинжилгээний үр дүн\цэвэрлэгээний флотацийн тоог нэмэгдүүлэх шаардлагатай. Тэр тохиолдолд 9698\%-ийн $\quad \mathrm{Ca}_{\mathrm{F2}}$-ын агуулгатай ФФ-98 маркийн хайлуур жоншны стандарт баяжмал гарган авна. Флотацийн аргаар баяжуулах урвалжийн горимыг дараах байдлаар тогтоов. Үүнд: Үндсэн флотацид: $\mathrm{N}_{\mathrm{a} 2} \mathrm{C}_{\mathrm{O} 3}-1000$ г/T, $\mathrm{N}_{\mathrm{a} 2}$ $\mathrm{Si}_{\mathrm{O} 3}-500 \Gamma / \mathrm{T}$, олеат натри $-300 \Gamma \backslash \mathrm{T}, \mathrm{T}-66$ -50г тт; хяналт.фл.: $\mathrm{N}_{\mathrm{a} 2} \mathrm{Si}_{\mathrm{O} 3}-100 \Gamma / \mathrm{T}, \mathrm{T}-66$ -50 г/T, ${ }_{\text {тфл }}={ }^{6 \mathrm{~L}}+{ }^{4 \mathrm{I}}$.

3. Жонш олборлогч компани, иргэн бүр баяжуулах үйлдвэр барьж байгуулах боломжгүй тул гар аргаар ангилалт хийсний дараа үлдсэн бага агуулгатай жоншоо Бор-Өндрийн баяжуулах үйлдвэр болон бусад шинээр баригдах үйлдвэрүүдэд нийлүүлэн хаягдлыг $\mathrm{CaF}_{2}$ багатайгаар боловсруулах боломжтой болох нь туршилт судалгааны ажлаас харагдаж байна. 


\section{Ашигласан бүтээлийн жагсаалт}

1. Жонш олборлогчдын зөвлөлгөөний эмхэтгэл. Бор-өндөр. 2012 он.

2. “хүдрийн биет 16-3” ордын жонш баяжуулах технологийн туршилтын тайлан УБ 2012 он

3. Henry Tebar., "Overview of the GAT fluorspar project in Mongolia" London. 2009.

4. Уул уурхайн үйлдвэрүүдийн 2009 оны бүтээгдэхүүн гаргалтын судалгаa. АМГ. 2010 он.

5. www.mram.gov.mn 